\title{
Interface Structures of Ag-Si Contacts with Thermal Properties of Frits in Ag Pastes
}

\author{
Seunggon Choi, Dongsun Kim, Jungki Lee and Hyungsun Kim ${ }^{\dagger}$ \\ School of Materials Engineering, Inha University 253 Yunghyun-dong, Nam-gu Incheon 402-751, Korea
}

(Received June 25, 2012 : Received in revised form July 18, 2012 : Accepted July 18, 2012)

\begin{abstract}
Ag pastes added to Bi-oxide frits have been applied to the electrode material of Si solar cells. It has been reported that frits induce contacts between the Ag electrodes and the Si wafer after firing. During firing, the control of interfaces among $\mathrm{Ag}$, the glass layer, and $\mathrm{Si}$ is one of the key factors for improving cell performance. Specifically, the thermo-physical properties of frits considerably influence Ag-Si contact. Therefore, the thermal properties of frits should be carefully controlled to enhance the efficiency of cells. In this study, the interface structures among Ag electrodes, glass layers, and recrystallites on an $\mathrm{n}^{+}$emitter were carefully analyzed with the thermal properties of lead-free frits. First, a cross-section of the area between the Ag electrodes and the Si wafer was studied in order to understand the interface structures in light of the thermal properties of the frits. The depth and area of the pits formed in the Si wafer were quantitatively calculated with the thermal properties of frits. The area of the glass layers between the $\mathrm{Ag}$ electrodes and $\mathrm{Si}$, and the distribution of recrystallites on the $\mathrm{n}^{+}$emitter, were measured from a macroscopic point of view with the characteristics of the frits. Our studies suggest that the thermophysical properties should be controlled for the optimal performance of Si solar cells; our studies also show why cell performance deteriorated due to the high viscosity of frits in Ag pastes.
\end{abstract}

Key words $\underline{\text { frit, }}$ thermal properties, Ag pastes, Ag recrystallites, Si solar cell.

\section{Introduction}

Frits have been used as one of the key components in the electrode materials of Si solar cells. Frits function on two ways for the electrode materials of solar cell. First, frits accelerate the sintering behaviors of metal powders. The other function is the adhesive between substrates and metal powders. ${ }^{1,2)}$ Frits of particular compositions based on lead-oxide have been used to fabricate Ag pastes for upper side electrodes. That is why lead-oxides induce the current paths between $\mathrm{Ag}$ electrodes and $\mathrm{Si}^{3)}$ To develop lead-free frits in Ag pastes for Si solar cells, many kinds of studies on the relationship among $\mathrm{Ag}$, frit, and $\mathrm{Si}$ wafers are needed to fabricate eco-friendly materials in Ag pastes.

Generally, it has been reported that the content of frits in $\mathrm{Ag}$ pastes is 2-5 wt\%. ${ }^{4)}$ Although a small quantity of frit is applied to the Ag pastes, it is needed for the ohmic contact that forms the current paths between the $\mathrm{Ag}$ electrodes and $\mathrm{Si}$ wafer after firing. ${ }^{5)}$ To improve the electrical properties of $\mathrm{Si}$ solar cells, the interface structures among Ag electrodes, glass layers, and $\mathrm{Si}$ should be optimally controlled. Specifically, it has been suggested that the penetration depth of $\mathrm{Ag}$ into $\mathrm{Si}$ and the thickness

${ }^{\dagger}$ Corresponding author

E-Mail : kimhs@inha.ac.kr (H. Kim) of glass layer between $\mathrm{Ag}$ and $\mathrm{Si}$ profoundly influence cell performances ${ }^{6-8)}$ However, there are few studies for the relation between the size, distribution of Ag recrystallites, the thickness, distribution of glass layers and the cell performances. Therefore, it is needed to quantitatively study the distribution of $\mathrm{Ag}$ recrystallites and glass layers between $\mathrm{Ag}$ electrodes and $\mathrm{Si}$ wafer.

In this study, the interface structures among Ag electrodes, glass layers, and recrystallites on the $\mathrm{n}^{+}$emitter were carefully analyzed with the thermal properties of lead-free frits. First, the cross-section between the Ag electrodes and $\mathrm{Si}$ wafer was studied to understand the interface structures with the thermal properties of frits. The area of the glass layers between the Ag electrodes and $\mathrm{Si}$, and the distribution of recrystallites on the $\mathrm{n}^{+}$ emitter were measured in macroscopic point of view with the characteristics of frits. The depth and area of pits formed into the $\mathrm{Si}$ wafer were quantitatively calculated with thermal properties of frits. Our studies suggest that thermophysical properties should be controlled for the optimal performance of Si solar cells and show that cell performance can be deteriorated with high viscosity of frits in Ag pastes.

\section{Experimental Procedure}

Glass frits were prepared by mixing the following oxide 
Table 1. Composition and particle sizes of three glasses $\left(\mathrm{R}_{2} \mathrm{O}_{3}: \mathrm{Al}_{2} \mathrm{O}_{3}, \mathrm{RO}_{2}: \mathrm{SiO}_{2}\right)$.

\begin{tabular}{ccccccccc}
\hline \multirow{2}{*}{ Glasses } & \multicolumn{3}{c}{ Composition $(\mathrm{mol} \%)$} & \multicolumn{3}{c}{ Frit size $(\mu \mathrm{m})$} & \multicolumn{2}{c}{ True density $\left(\mathrm{g} / \mathrm{cm}^{3}\right)$} \\
& $\mathrm{Bi}_{2} \mathrm{O}_{3}$ & $\mathrm{~B}_{2} \mathrm{O}_{3}$ & $\mathrm{ZnO}$ & $\mathrm{Al}_{2} \mathrm{O}_{3}+\mathrm{SiO}_{2}$ & $\mathrm{D}_{10}$ & $\mathrm{D}_{50}$ & $\mathrm{D}_{90}$ & Powders \\
\hline $\mathrm{BS} 1$ & 34 & 48 & 13 & 5 & 0.75 & 6.62 & 16.01 & 6.28 \\
$\mathrm{BS} 2$ & 34 & 53 & 8 & 5 & 0.81 & 7.33 & 17.5 & 6.02 \\
$\mathrm{BS} 3$ & 34 & 58 & 3 & 5 & 0.88 & 7.57 & 17.5 & 5.75 \\
\hline
\end{tabular}

powders with more than $99 \%$ purity: $\mathrm{Bi}_{2} \mathrm{O}_{3}, \mathrm{~B}_{2} \mathrm{O}_{3}, \mathrm{ZnO}$, $\mathrm{Al}_{2} \mathrm{O}_{3}$, and $\mathrm{SiO}_{2}$ (Aldrich, USA) (Table 1). The characteristics of the frits used for the work, including the composition, particle size, and true density of each frit, are shown in Table 1. The particle sizes of all of the frits were similarly controlled to minimize the effect of the frit size on the reaction between the $\mathrm{Ag}$ and $\mathrm{Si}$ wafer. The true density of the frits decreased with an increasing ratio of $\mathrm{B}_{2} \mathrm{O}_{3} / \mathrm{ZnO}(\mathrm{BS} 1: 3.7, \mathrm{BS} 2: 6.6$ and $\mathrm{BS} 3: 19.3)$. The batch compositions were well mixed in ball mills for 12 $\mathrm{h}$. The mixed batches were melted in an alumina crucible at $1000-1100^{\circ} \mathrm{C}$ for $30 \mathrm{~min}$ and quenched on a ribbon roll. The glasses were crushed and milled under wet conditions using a planetary mono mill(Fritsch, Pulverisette7, Germany). After milling, the frit size was analyzed by a particle size analyzer(LS230 \& N4PLUS, Coulter Corporation, USA). The Ag pastes were prepared with 84 wt $\%$ of Ag powder(HAG-250S, Changsung Corp., Korea), $12 \mathrm{wt} \%$ of the vehicle, and $4 \mathrm{wt} \%$ of each of the frits (BS1, BS2, and BS3) using a 3-roll mill for $30 \mathrm{~min}$.

A mono crystal silicon wafer was prepared from $<100>$ planar float-zone wafers with a sheet resistance of 50$60 \Omega /$ sq. A $70 \mathrm{~nm}$ thick plasma-enhanced chemical vapor deposition(PECVD) $\mathrm{SiN}_{\mathrm{x}}$ layer was deposited on the $\mathrm{n}^{+}$ emitter. The backside electrode was screen-printed with the Al pastes, and the Ag paste was then screen-printed on the $\mathrm{n}^{+}$emitter of the mono crystal silicon wafer. The $\mathrm{Ag}$ and $\mathrm{Al}$ electrodes were co-fired in a rapid thermal process(RTP) furnace, which provides accurate temperature control of the sample during firing. The glass transition temperature $\left(\mathrm{T}_{\mathrm{g}}\right)$ was determined by thermogravimetrydifferential thermal analysis(TG-DTA, Rigaku, Japan) at a heating rate of $10^{\circ} \mathrm{C} / \mathrm{min}$. The Littleton softening point $\left(\mathrm{T}_{\mathrm{s}}\right)$ was measured using a glass softening point determination system(Orton, SP-3A, USA). The half ball point
$\left(\mathrm{T}_{\mathrm{h}}\right)$ was analyzed using an automatic hot-stage microscope(HSM, Ajeon Co. Korea). The measurements were conducted in air with a heating rate of $10^{\circ} \mathrm{C} / \mathrm{min}$. The samples for these HSM measurements were made using a hand press to compress frits that were contained within a small cylindrical metal mold(about $3 \mathrm{~mm} \times 3 \mathrm{~mm}$ ).

The electrical properties of the cells were measured using standard I-V measurement to identify open-circuit voltage $\left(\mathrm{V}_{\mathrm{oc}}\right)$, short-circuit current $\operatorname{density}\left(\mathrm{J}_{\mathrm{sc}}\right)$, fill factor (FF), and efficiency. Furthermore, the series-resistancefree pseudo was also measured using the $S_{u n s} V_{o c}$ method, which is useful for examining the shunts and junction recombination. ${ }^{9)}$ The Ag electrodes, glass layers, and recrystallites on the $\mathrm{n}^{+}$emitter were removed selectively using $\mathrm{HNO}_{3} / \mathrm{HF} / \mathrm{HNO}_{3}$ solutions. The interface microstructures between the $\mathrm{Ag}$ electrodes and $\mathrm{Si}$ wafers were examined by scanning electron microscopy(SEM, Hitachi, Tokyo, Japan).

\section{Results and Discussion}

The thermal properties of frits fabricated in this study were shown in Table 2. The viscosity of each frit was different from that of the others when applied to the Ag paste. The viscosity of the frits increased in order of BS1, $\mathrm{BS} 2$, and BS3. These results seemed to be caused by increasing the content of the $\mathrm{B}_{2} \mathrm{O}_{3}$ in the glass. Generally, it has been well known that $\mathrm{B}_{2} \mathrm{O}_{3}$ plays the role of a network former in glass systems. On the other hand, the function of $\mathrm{ZnO}$ is the network modifier in glass. ${ }^{10)}$ Therefore, the level of glass network connection can increase with the increase of $\mathrm{B}_{2} \mathrm{O}_{3}$ and the decrease of $\mathrm{ZnO}$, which can induce a high viscous flow at increasing temperatures.

Furthermore, the compositions of the frits were con-

Table 2. Electrical properties of cells according to the thermal properties of frits.

\begin{tabular}{cccccccccc}
\hline Frits & $\begin{array}{l}{ }^{\mathrm{a}} \mathrm{T}_{\mathrm{g}} \\
\left({ }^{\circ} \mathrm{C}\right)\end{array}$ & $\begin{array}{c}{ }^{\mathrm{b}} \mathrm{T}_{\mathrm{s}} \\
\left({ }^{\circ} \mathrm{C}\right)\end{array}$ & $\begin{array}{c}{ }^{\mathrm{c}} \mathrm{T}_{\mathrm{h}} \\
\left({ }^{\circ} \mathrm{C}\right)\end{array}$ & $\begin{array}{c}{ }^{\mathrm{d}} \mathrm{T}_{\mathrm{l}} \\
\left({ }^{\circ} \mathrm{C}\right)\end{array}$ & $\begin{array}{c}\mathrm{J}_{\mathrm{sc}} \\
\left(\mathrm{mA} / \mathrm{cm}^{2}\right)\end{array}$ & $\begin{array}{c}\mathrm{V}_{\mathrm{oc}} \\
(\mathrm{V})\end{array}$ & $\begin{array}{c}\mathrm{FF} \\
(\%)\end{array}$ & $\begin{array}{c}\text { Effi. } \\
(\%)\end{array}$ & $\begin{array}{c}\text { PFF } \\
(\%)\end{array}$ \\
\hline BS1 & 436 & 504 & 590 & 765 & 33.27 & 0.623 & 70.74 & 14.65 & 79.9 \\
BS2 & 449 & 520 & 603 & 788 & 33.21 & 0.626 & 72.31 & 15.02 & 82.5 \\
BS3 & 460 & 530 & 620 & 807 & 33.27 & 0.626 & 70.25 & 14.63 & 82.6 \\
\hline
\end{tabular}

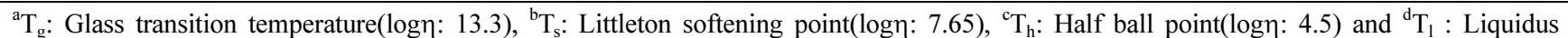
temperature $\left((\log \eta: 2.5 \mathrm{in} \mathrm{dPa} \cdot \mathrm{s})\right.$, respectively. $\mathrm{T}_{1}$ was calculated by empirical equation $\left(\mathrm{T}_{\mathrm{g}} / \mathrm{T}_{1} \approx 0.57\right)$ in $\mathrm{Bi}_{2} \mathrm{O}_{3}-\mathrm{B}_{2} \mathrm{O}_{3}-\mathrm{ZnO}_{\mathrm{O} O}$ glass systems. ${ }^{11)}$ 
trolled for the high viscous flow of the frits at increasing temperatures, taking into consideration the eutectic points in the phase diagram of the $\mathrm{Bi}_{2} \mathrm{O}_{3}-\mathrm{B}_{2} \mathrm{O}_{3}-\mathrm{ZnO}$ glass system. ${ }^{11)}$ The fluidity of frits with increasing temperatures profoundly influenced the interface structures between $\mathrm{Ag}$ and $\mathrm{Si}$, which determined the cell performances after firing. Controlling the $T_{s}, T_{h}$, and $T_{1}$ of frits above $T_{g}$ is the key for optimal cell performance. That is why the fluidity of frits at high temperatures is attributed to $T_{s}$, $T_{h}$, and $T_{l}$, which in turn affects the thickness of the glass layers between the $\mathrm{Ag}$ and $\mathrm{Si}$, the penetration depth of the recrystallites into the $\mathrm{Si}$, and the distribution of recrystallites on the $\mathrm{n}^{+}$emitter.

The electrical properties of the fabricated solar cells showed an interesting tendency with increasing frit viscosity (Table 2). The efficiency of the cell improved with BS2 compared to BS1 in Ag pastes. However, the efficiency of the cell was lower from BS2 to BS3 in Ag pastes as the viscosity of the frits used in the $\mathrm{Ag}$ pastes increased. Considering the value(above $80 \%$ ) of the pseudo fill factor(PFF), there is no shunt in the pn junction due to the excessive penetration of the $\mathrm{Ag}$ into the $\mathrm{Si}$ as the viscosity of the frits increased. ${ }^{9)}$ Although the values of the short-circuit current $\operatorname{density}\left(\mathrm{J}_{\mathrm{sc}}\right)$, and opencircuit voltage $\left(\mathrm{V}_{\mathrm{oc}}\right)$ did not change considerably with the viscosity of the frits, the fill factor(FF) was affected by the viscosity of frits fabricated.

The value of the FF is strongly dependent on the series resistance $\left(R_{s}\right)$ and the shunt resistance $\left(R_{\text {sh }}\right)$, which is attributed to the glass layers between the $\mathrm{Ag}$ and $\mathrm{Si}$, and the diffusion of silver or certain impurities into the pn junction. ${ }^{12)}$ It was reported that the thick glass layer between the $\mathrm{Ag}$ and Si leads to high contact resistances, and the excessive penetration of $\mathrm{Ag}$ and impurities in the pn junction induces a low $\mathrm{V}_{\mathrm{oc}}$, which deteriorates the $\mathrm{FF}$ and the efficiency. ${ }^{7)}$ To determine the reason why the value of the FF decreased with increasing viscosity of the frits, the contact resistances between the Ag electrodes and Si were studied. Fig. 1 shows the contact resistances $\left(\mathrm{R}_{\mathrm{c}}\right)$ between the fingers and the Si wafer with different frits in Ag pastes after firing. The electrical properties of the cells deteriorated with a high resistance between the $\mathrm{Ag}$ and $\mathrm{Si}$, which disrupted the electron transfer from the $\mathrm{Si}$ wafer into the $\mathrm{Ag}$ electrodes. Therefore, these high contact resistances can be attributed to the interface structures between the Ag electrodes and $\mathrm{Si}$ wafer.

To understand the effects of the interface structures on the contact resistances, the interfaces between the $\mathrm{Ag}$ electrodes and the $\mathrm{Si}$ wafer were studied. Fig. 2 shows the cross-sectional SEM images between the fingers(1-a, 1-b, and 1-c in Fig. 1) and the Si wafer. As the viscosity of the frits increased, the penetration depth of the recrystallites decreased from $670 \mathrm{~nm}$ (a) to about $350 \mathrm{~nm}$ (c)
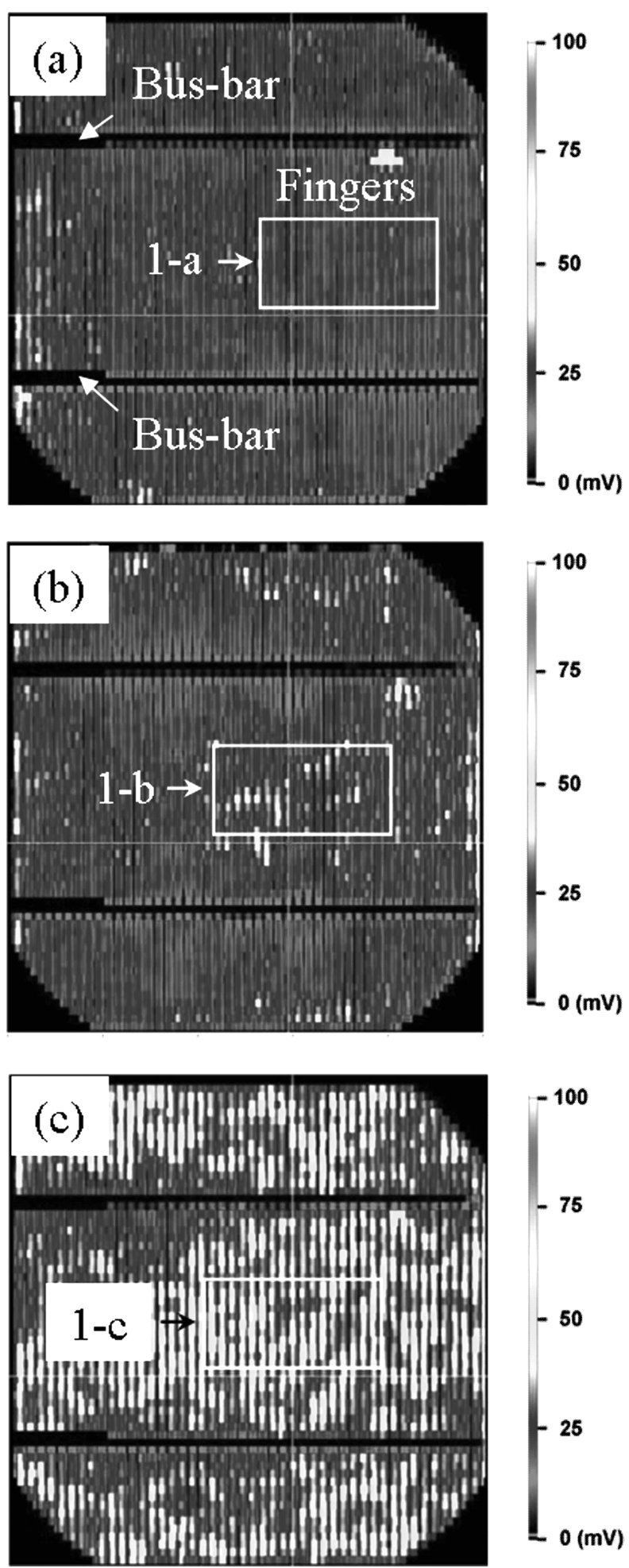

Fig. 1. Contact resistance $\left(\mathrm{R}_{\mathrm{c}}\right)$ mapping of solar cells to which (a) $\mathrm{BS} 1$, (b) BS2 and (c) BS3 in Ag pastes were applied. $\mathrm{R}_{\mathrm{c}}$ is the contact resistance between the $\mathrm{Ag}$ electrodes and the $\mathrm{Si}$ wafer.

in Fig. 2. In case of the Ag pastes with BS1 added, the direct connections between the $\mathrm{Ag}$ and $\mathrm{Si}$ mostly formed without the glass layers. On the other hand, as the 

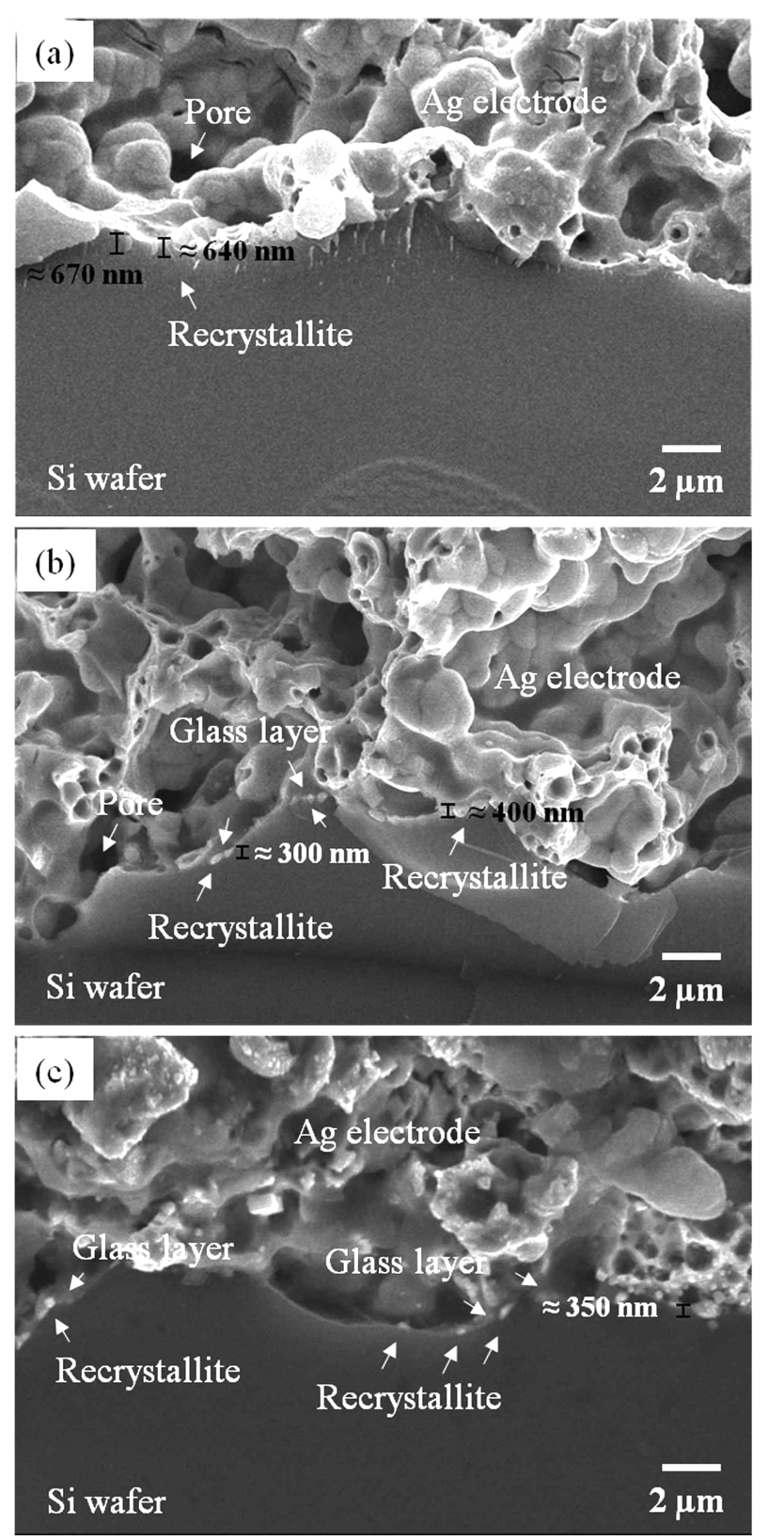

Fig. 2. SEM cross-sectional images between the Ag electrode with each frit added (a) BS1, (b) BS2, (c) BS3 and the Si wafer, with the recrystallites penetrated in to the $\mathrm{Si}$ wafer, and with pores and glasses formed at the interface of the $\mathrm{Ag}$ electrode(top) and the $\mathrm{Si}$ wafer(bottom). The penetration depth of the recrystallites into the Si was (a) about $640-670 \mathrm{~nm}$ (b) $300-400 \mathrm{~nm}$ and (c) $<350 \mathrm{~nm}$.

viscosity of the frits increased(BS2-3), recrystallites and glass layers between the Ag electrodes and $\mathrm{Si}$ wafers were detected compared to using BS1.

The distribution of the glass layers and the recrystallites on the $\mathrm{n}^{+}$emitter were analyzed with the thermal properties of the frits in Ag pastes. The glass layers between the $\mathrm{Ag}$ electrodes and the $\mathrm{Si}$ wafer broadly formed as the viscosity of the frits increased as shown in
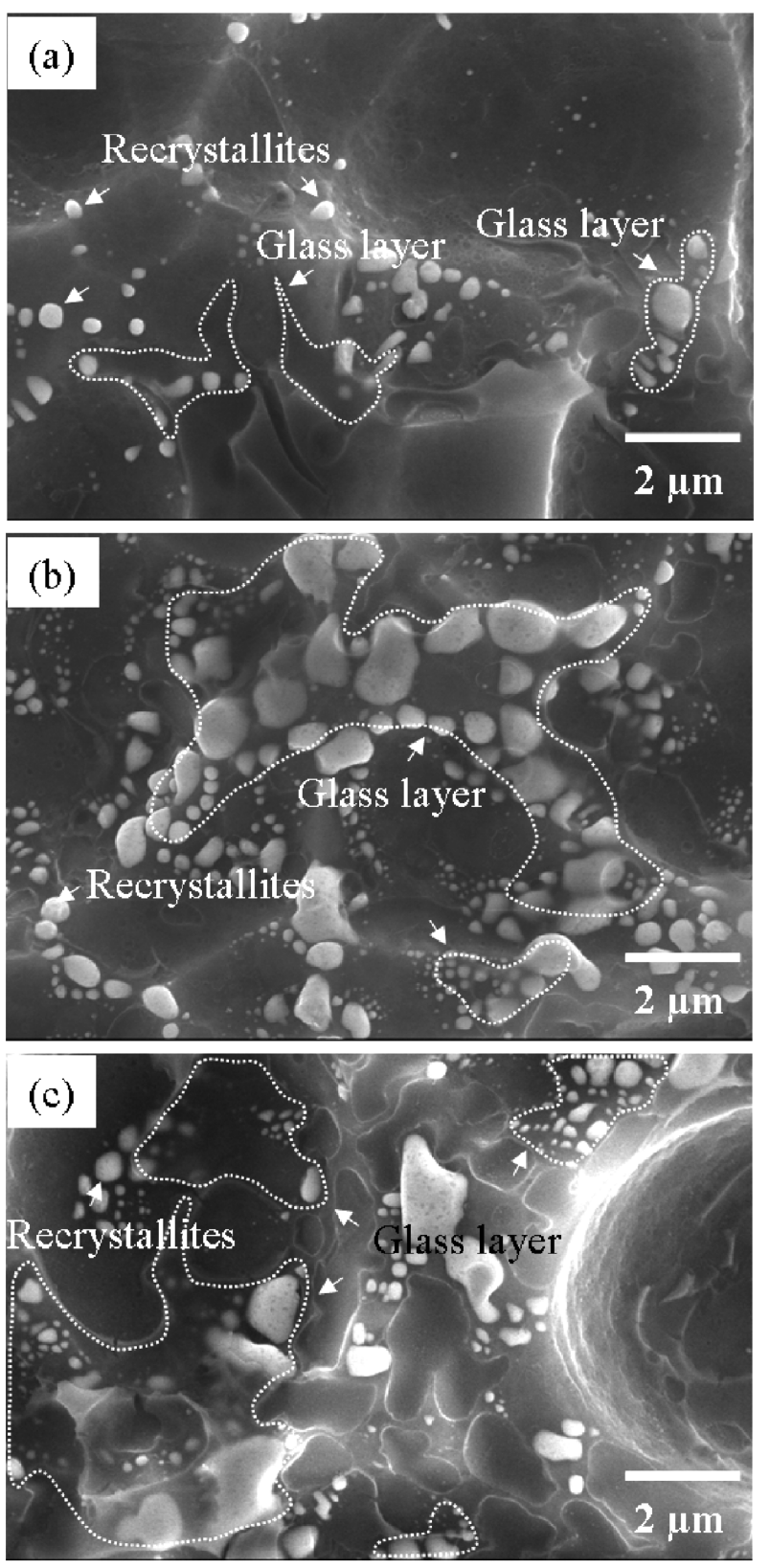

Fig. 3. SEM images of the surface of the $\mathrm{n}^{+}$emitter silicon after removing the Ag electrode with each frit added (a) BS1, (b) BS2, (c) $\mathrm{BS} 3$ using $\mathrm{HNO}_{3}$ solution. The dotted line shows the glass layers formed on the Si wafer.

Fig. 3. The recrystallites on the $\mathrm{n}^{+}$emitter were buried under the glass layers. Therefore, it can be inferred that the contact resistance between the fingers and $\mathrm{Si}$ should increase due to the glass layers formed between the $\mathrm{Ag}$ electrodes and $\mathrm{Si}$, which obstructs the electron transfer from the $\mathrm{Si}$ wafer to $\mathrm{Ag}$ electrodes.

The size of recrystallites on the $\mathrm{n}^{+}$emitter as well as that of the glass layers also increased with the higher viscosity of the frits as shown in Fig. 4. To determine why the glass layers and recrystallites increased in size 

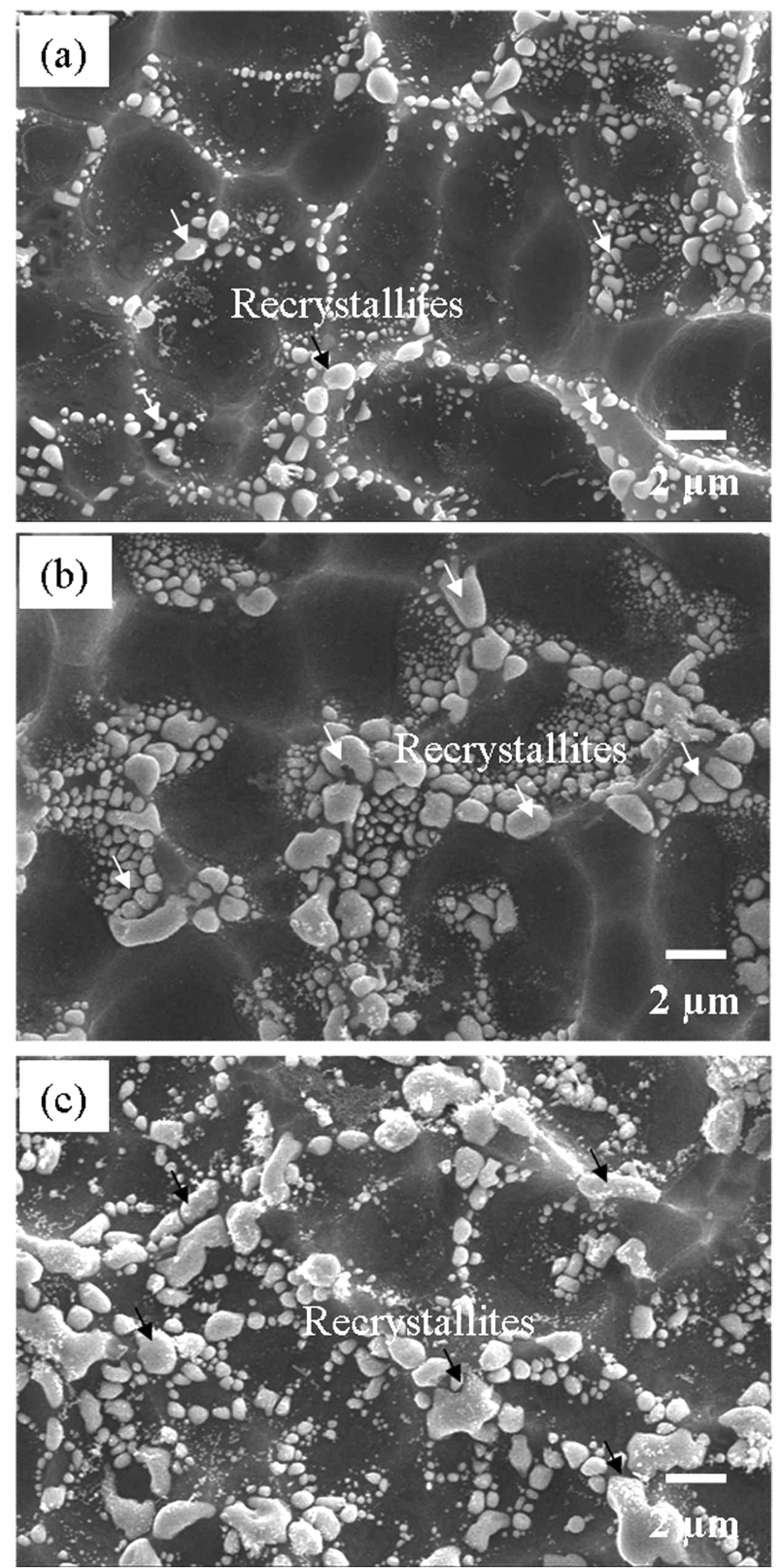

Fig. 4. SEM images of the surface of the $\mathrm{n}^{+}$emitter silicon after removing the $\mathrm{Ag}$ electrode with each frit added (a) BS1, (b) BS2, (c) BS3 and the glass layers using $\mathrm{HNO}_{3}$ solution.

with the increasing viscosity of the frits, the volume fraction of the frit in each $\mathrm{Ag}$ paste was measured. The true density of the frits was in the range of 6.28 to $5.75 \mathrm{~g} / \mathrm{cm}^{3}$ (in Table 1). In this study, the content of the frits was fixed at $4 \mathrm{wt} \%$ excluding the $\mathrm{Ag}$ powders and vehicles. Therefore, the volume fraction of the frits in the $\mathrm{Ag}$ pastes has to increase with decreasing the true density of frits. As the true density of frits decreased, it was concluded that the volume of the frits in Ag pastes increased and thus the glass layers between the $\mathrm{Ag}$ electrodes and $\mathrm{Si}$ wafer formed more in $\mathrm{Ag}$ pastes with the BS3 frit

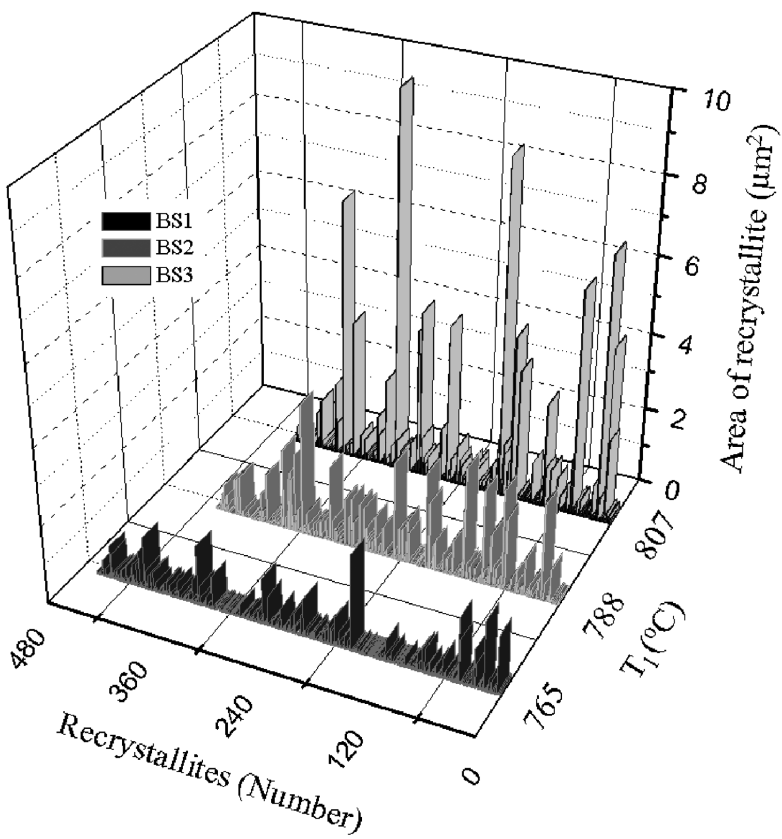

Fig. 5. The number and the area of recrystallites formed on the $n^{+}$ emitter with increasing liquidus temperatures of frits(BS1, BS2 and BS3) in the Ag pastes.

added than in the Ag pastes with the BS1-2 frits added.

In Fig. 5, the number and area of recrystallites formed on the $\mathrm{n}^{+}$emitter are shown with the increasing $\mathrm{T}_{1}$ of the frits. Although the number of recrystallites was reduced from 460 to 404 and finally 391 as $T_{1}$ increased, the maximum area of the recrystallites increased from $2.49 \mu \mathrm{m}^{2}$ to $3.44 \mu \mathrm{m}^{2}$ and finally $9.78 \mu \mathrm{m}^{2}$. It was expected that as the $T_{1}$ of the frits decreased, the reaction kinetics between the $\mathrm{Ag}$ and frits would be fast and thus numerous recrystallites would be formed on the $\mathrm{n}^{+}$emitter. However, it was found that the size of recrystallites decreased with a decreasing volume of frits in the order of BS3, $\mathrm{BS} 2$, and BS1in Ag pastes.

Fig. 6 quantitatively indicates the total area of the glass area and recrystallites formed on the $\mathrm{n}^{+}$emitter with the volume fraction of the frits in $\mathrm{Ag}$ pastes. Although the difference in the volume fraction of the frits in the $\mathrm{Ag}$ pastes is small, it could profoundly influence the interface structures between the $\mathrm{Ag}$ and the $\mathrm{Si}$ wafer. The total area of the glass layers formed between the $\mathrm{Ag}$ and the $\mathrm{Si}$ increased from $103.9 \mu \mathrm{m}^{2}$ to $158.6 \mu \mathrm{m}^{2}$ and then $207.3 \mu \mathrm{m}^{2}$ in the area of $430 \mu \mathrm{m}^{2}$ as the volume fraction of the frits increased. The total area of the recrystallites on the $\mathrm{n}^{+}$emitter also increased from $78.4 \mu \mathrm{m}^{2}$ to 113.4 $\mu \mathrm{m}^{2}$ and finally to $140.0 \mu \mathrm{m}^{2}$ in the area of $430 \mu \mathrm{m}^{2}$. These results mean that the distribution of the glass layers and the recrystallites are considerably affected by the volume fraction of the frits in the $\mathrm{Ag}$ pastes.

The viscosity of the frits was strongly related to the 


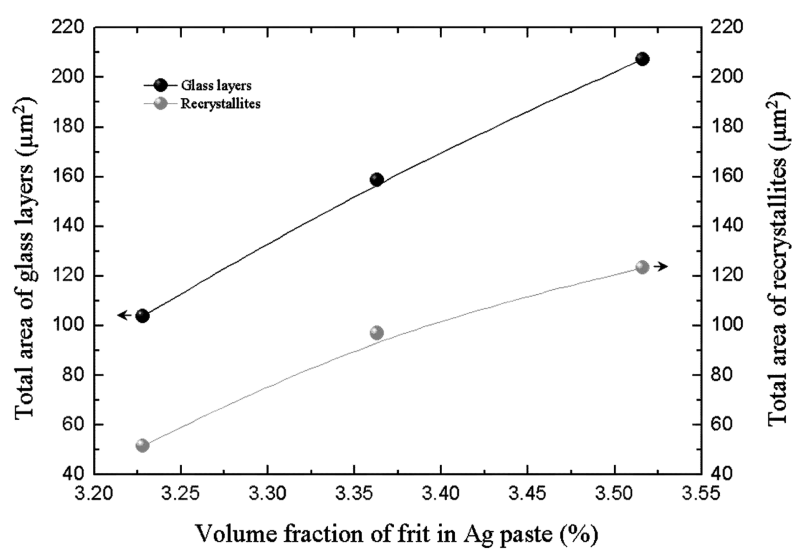

Fig. 6. Total area of the glass layers formed between the Ag electrodes and the $\mathrm{Si}$ wafer and the recrystallites on the $\mathrm{n}^{+}$emitter in an area of $430 \mu \mathrm{m}^{2}$ according to the volume fraction of the frit in the Ag pastes. The volume fraction of each frit was calculated by the equation(volume of frit/volume of(Ag powders + frit) $) \times 100 \%$.

penetration depths of the recrystallites(ie. the depths of pits) into the wafer as shown in Fig. 7. The depths of the pits were reduced with increasing viscosity of the frits. The ranges of the pit depths measured with the BS1 frit were from $140 \mathrm{~nm}$ to about $595 \mathrm{~nm}$. However, the pit depths were from $38 \mathrm{~nm}$ to $274 \mathrm{~nm}$ and from $30 \mathrm{~nm}$ to about $189 \mathrm{~nm}$ with the BS2 and BS3 frits, respectively. Therefore, the excessive penetration of the recrystallites into the pn junction with the BS1 frit led to a low $\mathrm{V}_{\mathrm{oc}}$ (Table 2) compared to the other frits(BS2 and BS3). The shape of the pits was converted from an inverted pyramid, or a trapezoid to an ellipse as the viscosity of frits increased. These shapes are similar to the shapes of the pits formed into the Si by wet etching methods. In case of the (100) Si wafer, the pits of the inverted pyramid are formed into the Si by excessive etching and the trapezoidal types of pits are created by the shallow etching of Si with anisotropic wet etching, respectively. ${ }^{13)}$ Therefore, it can be induced that the depths of the pits into the Si in this study were reduced with the shallow etching by the reaction among $\mathrm{Ag}$, frits and $\mathrm{Si}$ wafer with the high viscosity frits. The number and area of the pits in $\mathrm{Si}$ wafers were quantitatively calculated with the increasing $\mathrm{T}_{1}$ of the frits.

As the $T_{1}$ increased, the number of pits increased from 172 to 270 and decreased from 270 to 199 (Fig. 8). On the other hand, the maximum area of the pits increased from $0.8 \mu \mathrm{m}^{2}$ to $2.85 \mu \mathrm{m}^{2}$ and then to $5.43 \mu \mathrm{m}^{2}$ with the increasing $T_{1}$ of the frits. It was concluded that the area of the pits can be expanded with increasing the volume of the frits in $\mathrm{Ag}$ pastes with the increasing $\mathrm{T}_{1}$ of the frits fabricated in this study. The most numerous pits were detected in BS2. These findings mean that the current paths from the $\mathrm{Si}$ to the $\mathrm{Ag}$ electrodes formed more
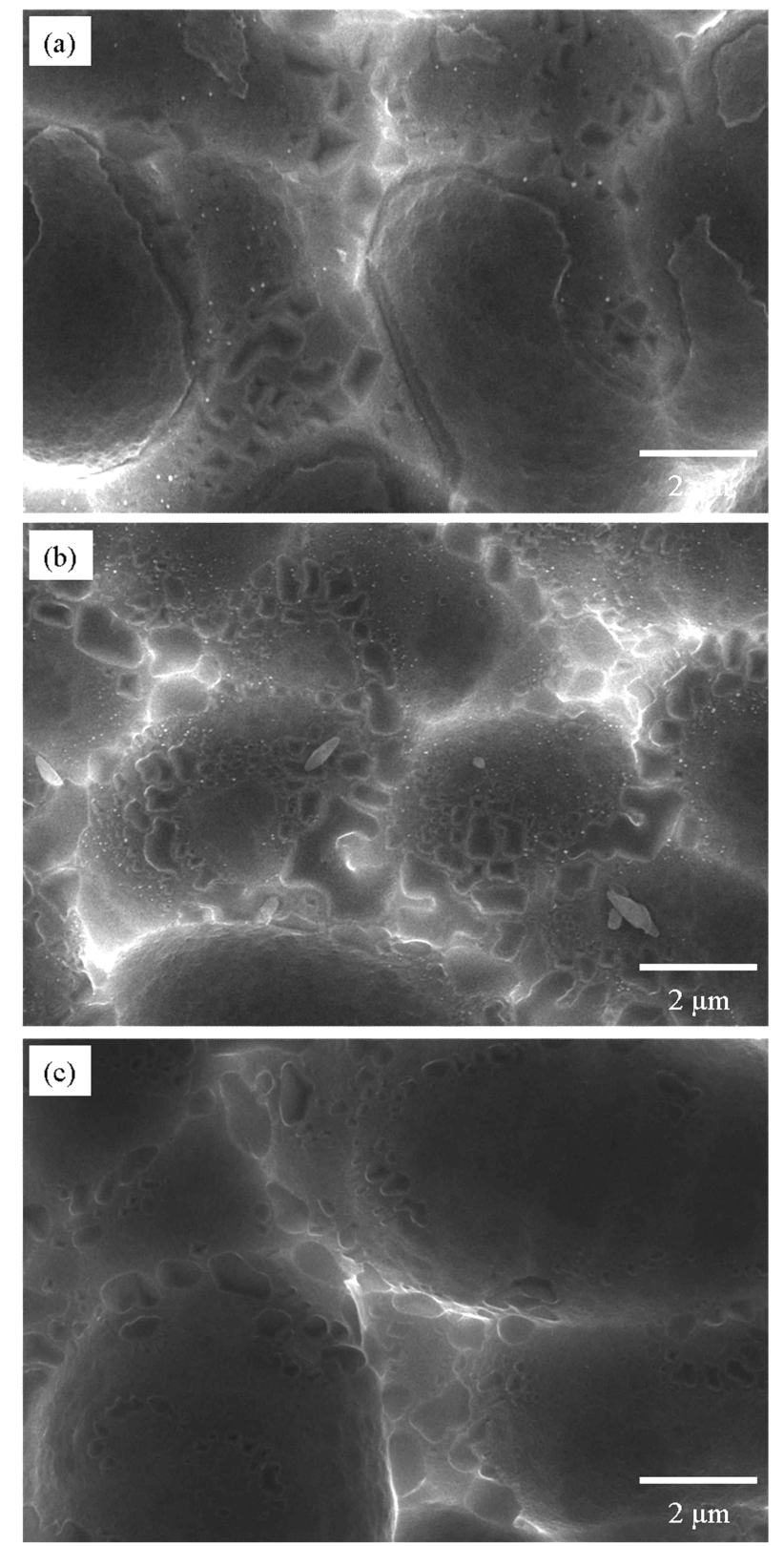

Fig. 7. SEM images of pits shaped like (a) an inverted pyramid, (b) a trapezoid and (c) an ellipse formed into the $\mathrm{n}^{+}$emitter silicon after removing the Ag electrode with each frit added (a) BS1, (b) BS2 and (c) $\mathrm{BS} 3$ to the glass layers and the recrystallites using $\mathrm{HNO}_{3} / \mathrm{HF} /$ $\mathrm{HNO}_{3}$ solutions. The calculated penetration depth of the recrystallites into the Si was (a) about $140-595 \mathrm{~nm}$, (b) $38-274 \mathrm{~nm}$ and $30-$ $189 \mathrm{~nm}$, respectively.

extensively with BS2 than with BS1 and BS3. Thus the efficiency of the cell fabricated with the $\mathrm{Ag}$ paste to which the BS2 frit was added, and with the proper penetration of recrystallites into $\mathrm{Si}$, was the highest.

\section{Conclusion}

The interface structures between the Ag electrode and 


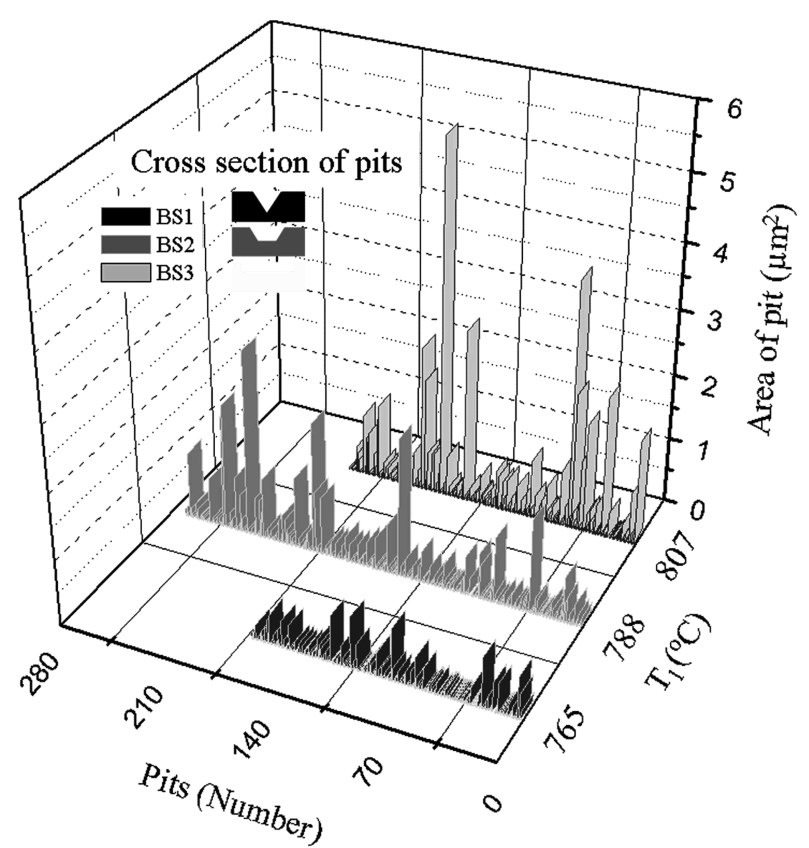

Fig. 8. The area of the pits formed on the Si wafer with different frits(BS1, BS2 and BS3) in the Ag pastes. The pit depths were reduced with the increasing viscosity of the frits.

$\mathrm{Si}$ wafer in the relatively high efficiency cells were quantitatively studied with the thermal properties of frits. The difference in the thermal properties of the frits obviously influenced the penetration depth of the recrystallites into the $\mathrm{n}^{+}$emitter, which influenced the shunt resistance. In particular, the subtle distinction in the volume fraction of the frits in each of the Ag pastes considerably affected the formation of glass layers between the $\mathrm{Ag}$ electrodes and the Si wafer, which increased the series resistance and deteriorated the cell performance. Our studies suggest that minutely controlling the thermal properties of the frits is needed for the proper penetration of the recrystallites into the $\mathrm{Si}$ to prevent current losses in the pn junction. Furthermore, considering the volume fraction of the frits in the $\mathrm{Ag}$ pastes, the quantity of the frits in $\mathrm{Ag}$ pastes should be controlled for optimal cell performance.

\section{Acknowledgement}

This work is the outcome of a Manpower Development Program(2009-N-BL-HM-2-03-0000) for Energy \& Resources supported by the Ministry of Knowledge and Economy(MKE).

\section{References}

1. G. C. Cheek, R. P. Mertens, R. V. Overstraeten and L. Frisson, IEEE Trans. Electron Dev., 31(5), 602 (1984).

2. J. K. Lee, S. H. Park and G. S. Yang, Kor. J. Mater. Res., 18(5), 283 (2008) (in Korean).

3. C. Ballif, D. M. Huljić, G. Willeke and A. Hessler-Wyser, Appl. Phys. Lett., 82(12), 1878 (2003).

4. C. H. Lin, S. Y. Tsai, S. P. Hsu and M. H. Hsieh, Sol. Energ. Mater. Sol. Cell., 92, 1011 (2008).

5. M. Prudenziati, L. Moro, B. Morten, F. Sirotti and L. Sardi, Active and Passive Elec. Comp., 13(3), 133 (1989).

6. S. Kontermann, M. Hörteis, M. Kasemann, A. Grohe, R. Preu, E. Pink and T. Trupke, Sol. Energ. Mater. Sol. Cell., 93(9), 1630 (2009).

7. M. M. Hilali, S. Sridharan, C. Khadilkar, A. Shaikh, A. Rohatgi and S. Kim, J. Electron. Mater., 35(11), 2041 (2006).

8. D. Kim, S. Hwang and H. Kim, J. Korean Phys. Soc., 55(31), 1046 (2009).

9. R. A. Sinton and A. Cuevas, in Proceedings of the 16th European Photovoltaic Solar Energy Conference, (Glasgow, UK, May, 2000), p. 1152-1155.

10. H. Scholze, Glass: Nature, Structure, and Properties, p. 161, Springer, New York, USA (1991).

11. Y. J. Kim, S. J. Hwang and H. S. Kim, Mater. Sci. Forum, 510-511, 578 (2006).

12. M. M. Hilali, K. Nakayashiki, C. Khadilkar, R. C. Reedy, A. Rohatgi, A. Shaikh, S. Kim and S. Sridharan, J. Electrochem. Soc., 153(1), A5 (2006).

13. M. Kohler, Etching Microsystem Technology, p. 93-94, Wiley, New York, USA(1999). 